JURNAL RESPIRASI

JR

Vol. 2 No. 3 September 2016

\title{
Kepositifan Induksi Sputum NaCl 3\% dan Teknik Broncho Alveolar Lavage pada Pneumocystis Pneumonia
}

Isnin Anang Marhana, Retna Dwi Puspitarini

Departemen/SMF Pulmonologi dan Ilmu Kedokteran Respirasi Universitas Airlangga Surabaya

\begin{abstract}
Background: Pneumocystis pneumonia $(P C P)$ is a major cause of morbidity and mortality in patients immunocompromised. The incidence of PCP in HIV are 0.3 cases per 100 person years with mortality 63.6\%. The diagnosis of PCP experiencing difficulties because of the causative organism can not be cultured. Several attempts were carried out to obtain a representative sample sputum through induced sputum and bronchoalveolar lavage. This study compared the use of induced sputum and bronchoalveolar lavage (BAL) in the diagnosis of PCP. Methods: From September, 2015, to February, 2016, HIV-positive patients 21 to 65 years old were evaluated at UPIPI ward, Soetomo hospital with suspicion of PCP based on clinical and radiological findings. Sputum induction and BAL was done for Giemsa staining. Result: Thirteen subjects with a mean age of 40, with 11 male (84.6\%). All subjects with chief complain shortness of breath and common complain cough with hard to expetorate. Most frequent risk factors was freesex. Mean of subjects received treatment cotrimoxazole is 3.5 days. Six subjects have been treated with ART. Mean of LDH serum was $554.62 \pm$ 376.707 U/l. Interstitial infiltrate was the most frequent radiological pattern (76.9\%). Most bronchoscopy examinations showed normal results (84.6\%). Both Giemsa staining from induced sputum and BAL showed no positive results. Conclusion: All Giemsa staining from both induced sputum and BAL can not be compared due to no positive result.
\end{abstract}

Key words: Pneumocystis pneumonia, induced sputum, bronchoalveolar lavage, HIV, therapy anti-retroviral

Correspondence: Isnin Anang Marhana, Departemen Pulmonologi dan Ilmu Kedokteran Respirasi, Fakultas Kedokteran, Universitas Airlangga/RSUD Dr. Soetomo. Jl. Mayjen. Prof Dr. Moestopo 6-8 Surabata 60286. E-mail: marhanadr@yahoo.com

\section{PENDAHULUAN}

Pneumocystis merupakan suatu patogen fungal oportunistik yang berpotensi menyebabkan pneumonia yang mematikan pada orang dengan immunocompromised. Pada era 1980-an, seiring dengan epidemi Human Immunodeficiency Virus (HIV), prevalensi PCP meningkat drastis dan secara luas dikenal sebagai suatu infeksi oportunistik. ${ }^{1,2}$ PCP terjadi pada $75-80 \%$ pasien HIV dan lebih dari $90 \%$ kasus terjadi pada pasien dengan Cluster of Differentiation $4(\mathrm{CD} 4)<200 \mathrm{sel} / \mu \mathrm{L}$. Pada awal epidemi HIV, insiden PCP 20 kasus/100 orang/tahun pada pasien HIV dengan CD4 < 200 sel/ $\mu$ L. Tahun 1990-an dengan penggunaan luas profilaksis dan inisiasi antiretrovirus (ARV) pada pasien-pasien HIV, jumlah kasus PCP menurun. Insiden PCP menurun $3,4 \%$ per tahun selama periode tahun 1992-1995 dan terjadi penurunan kasus 21,5\% selama kurun waktu 1996-1998. Data dari studi EuroSIDA, terjadi penurunan kasus PCP 4,9 kasus per 100 orang per tahun menjadi 0,3 kasus per 100 orang per tahun setelah tahun $1998 .^{3,4,5}$

Walaupun angka insiden PCP mengalami penurunan setelah era anti retroviral terapi (ART), namun PCP masih menjadi penyebab penting infeksi oportunistik pada pasien HIV. Angka kejadian gagal napas akut yang memerlukan ventilasi mekanik pada pasien HIV dengan PCP sebesar 40-60\% dengan angka kematian 63,6\%.6,7

Beberapa faktor predisposisi terjadinya PCP pada pasien HIV yang belum menerima terapi efektif ART yaitu pasien belum mendapat terapi profilaksis, kandidiasis oris, leukoplakia di mulut, penurunan berat badan yang drastis, terjadinya pneumonia bakterial yang berulang, riwayat 
PCP sebelumnya dan RNA (Ribo Nukleat Acid) HIV (viral load) yang tinggi. ${ }^{7,8}$

Diagnosis PCP mengalami kesulitan karena organisme penyebabnya tidak bisa di kultur. Salah satu alat diagnostik yang penting pada infeksi PCP adalah kecurigaan tanda klinis. Pada setting klinis yang tepat, seorang pasien immunocompromised dengan sesak akut atau gejala baru pneumonia, dengan atau tanpa temuan radiologis, harus dievaluasi lebih lanjut adanya PCP, khususnya bila tidak mendapatkan kemoprofilaksis. ${ }^{1,8}$

Spesimen untuk pemeriksaan harus diusahakan dari saluran napas bawah dengan kualitas yang baik dan diusahakan sebaiknya sebelum pemberian antibiotik. Namun pada kenyataannya, tidak jarang dijumpai kendala dalam memperoleh sediaan sputum yang representatif untuk pemeriksaan giemsa maupun gomori. Diagnosis PCP membutuhkan pemeriksaan mikroskopis untuk mengidentifikasi Pneumocystis dari sumber yang relevan, karena Pneumocystis tidak dapat dikultur. Kendala yang sering dihadapi antara lain: penderita batuk tidak berdahak, atau tidak mampu untuk mengekspektorasikan sputum atau batuk yang tidak efektif, sering sediaan hanya berupa saliva, sehingga sulit mendapatkan sputum yang representatif. Kenyataan diatas merupakan masalah yang perlu dicari alternatif jalan pemecahannya. Beberapa upaya yang dilaksanakan untuk memperoleh sampel sputum yang representatif yaitu melalui induksi sputum dan bronkoskopi.

Induksi sputum bertujuan untuk mengumpulkan sampel yang cukup dari saluran napas individu yang tidak dapat mengeluarkan sputum dengan spontan. Dengan induksi didapatkan sputum yang adekuat dari saluran napas bawah. Penelitian yang melakukan induksi sputum dengan inhalasi larutan $\mathrm{NaCl}$ 3\% memperoleh hasil sputum yang representatif. Sputum induksi merupakan prosedur yang aman dan efektif.

Bronkoskopi adalah prosedur medis memasukkan pipa ke jalan napas melalui hidung atau mulut. Fiber Optic Bronchoscopy (FOB) dengan BAL merupakan tindakan yang mudah, aman, cepat dan dapat dipercaya. FOB secara luas digunakan sebagai prosedur untuk menegakkan diagnosis pasien immunocompromised dengan kelainan infiltrat di parunya.

FOB mampu menegakkan diagnosis PCP sebesar $100 \%$, infeksi bakterial $78 \%$, virus $83 \%$, dan BAL sendiri mampu menegakkan diagnosis PCP sebesar 8998\%. Penelitian Velez dkk yang dilakukan di Kolombia, sensitivitas BAL untuk menegakkan infeksi di paru pada pasien immunocompromised 75,9\% dan spesifisitas $86 \%$. Penelitian di Amerika dan Spanyol, sensitivitas BAL untuk infeksi di paru pada pasien immunocompromised 52-81\% dan pada penyakit infeksi sebesar 61-72\%.9,10,11

Penelitian Silva dkk, induksi sputum untuk menegakkan diagnosis PCP memiliki sensitivitas 58,5\%, spesifisitas $81,8 \% .{ }^{12}$ Penelitian Carmona dan Limper, induksi sputum memiliki sensitivitas 50-90\% untuk menegakkan diagnosis PCP. ${ }^{1}$
Pada pasien HIV, diferensial diagnosis penyakitnya sangat banyak meliputi infeksi dan non infeksi. Pada pasien HIV, kondisi cepat sekali memburuk (akut) dan sering terjadi hipoksia yang progresif. Penegakan diagnosis sering terlambat pada pasien ini dan dapat menyebabkan meningkatnya angka kematian dan induksi sputum maupun bronkoskopi sangat diperlukan untuk menegakkan diagsosis awal sehingga manajemen terapi dapat lebih optimal. Ketepatan dalam menegakkan diagnosis dan menemukan penyebab pneumonia pada pasien immunocompromised akan memberikan outcome yang baik.

Berdasarkan uraian di atas, maka penelitian ini dilaksanakan untuk meningkatkan ketepatan diagnosis Pneumocystis pneumonia dengan cara induksi sputum $\mathrm{NaCl}$ $3 \%$ dan tehnik BAL serta membandingkan manakah nilai kepositifan yang lebih baik antara induksi sputum $\mathrm{NaCl}$ $3 \%$ dan tehnik BAL.

\section{METODE}

Penelitian ini merupakan studi analitik cross sectional, dilakukan di ruang UPIPI RSUD Dr. Soetomo Surabaya. Sampel penelitian merupakan pasien HIV yang di rawat inap di Ruang UPIPI RSUD Dr. Soetomo yang di diagnosis PCP secara klinis dan radiologis dan memenuhi kriteria inklusi dan diambil dengan cara consecutive sampling.

Kriteria inklusi adalah pasien berusia 21-65 tahun, pasien laki-laki atau perempuan yang di suspek PCP dengan keluhan gejala klinis sub akut minimal 7 hari seperti batuk non produktif atau sedikit produktif, sesak napas yang progresif, demam yang tidak tinggi dan malaise atau didapatkan gambaran radiologis infiltrat interstitial, mendapat ARV maupun tidak serta bersedia ikut dalam penelitian untuk menjalani prosedur tindakan BAL dengan mengisi informed consent.

Induksi sputum adalah prosedur dengan cara inhalasi larutan $\mathrm{NaCl} 3 \%$ untuk mengumpulkan sampel yang cukup dari saluran napas individu yang tidak dapat mengeluarkan sputum dengan spontan.

Bonchoalveolar lavage (BAL) adalah teknik pengambilan spesimen saluran napas bagian bawah dengan cara memasukkan cairan fisiologis $(\mathrm{NaCl} 0,9 \%)$ melalui alat bronkoskop dan kemudian mengambilnya kembali. Pasien suspek PCP adalah pasien HIV dengan keluhan gejala klinis sub akut minimal 7 hari seperti batuk non produktif atau sedikit produktif, sesak napas yang progresif, demam yang tidak tinggi dan malaise dan didapatkan gambaran radiologis infiltrat interstitial bilateral. Diagnosis pasti PCP apabila didapatkan gambaran bentuk tropik dikelilingi eksudat berbuih dengan pewarnaan giemsa. Data dalam latar belakang akan dianalisis secara deskriptif, dilakukan perbandingan kepositifan pemeriksaan Giemsa antara induksi sputum $\mathrm{NaCl} 3 \%$ dengan teknik BAL dan analisis data dilakukan dengan komputer memakai program SPSS. 
Tabel 1. Karakteristik pasien

\begin{tabular}{lc}
\hline \multicolumn{1}{c}{ Subjek Penelitian } & \\
\hline Jenis kelamin & $11(84,6 \%)$ \\
$\quad$ Laki-laki & $2(15,4 \%)$ \\
$\quad$ Perempuan & $40 \pm 9,20$ \\
\hline Usia & $6(46,2 \%)$ \\
\hline Terapi ARV & $7(53,8 \%)$ \\
$\quad$ Pernah & \\
$\quad$ Tidak pernah & $7(53,8 \%)$ \\
\hline Penyakit lain & $5(38,4 \%)$ \\
$\quad$ Pnemonia bakterial & $13(100 \%)$ \\
$\quad$ TB Paru & $2(15,4 \%)$ \\
Candidiasis oris & $1(7,7 \%)$ \\
$\quad$ Pneumotoraks & $13(100 \%)$ \\
Diare kronis & $6,380 \pm 2,126$ \\
\hline $\mathrm{Sesak}$ napas & $81,26 \pm 7,58 \%$ \\
\hline $\mathrm{Leukosit}^{\mathrm{Granulosit}}$ & $108,48 \pm 52,488$ \\
\hline $\mathrm{pO}_{2}$ & $96,5 \pm 3,69 \%$ \\
\hline $\mathrm{SaO}_{2}$ & $186,23 \pm 88,635$ \\
\hline $\mathrm{AaDO}_{2}$ & \\
\hline
\end{tabular}

\section{HASIL}

Penelitian ini dilakukan pada Ruang UPIPI RSUD Dr. Soetomo. Jumlah sampel sebanyak 13 pasien dengan klinis dan foto toraks mendukung PCP. Berikut adalah gambaran 13 sampel penelitian yang dideskriptifkan menurut jenis kelamin, kategori usia dan keluhan yang dialami baik keluhan utama maupun keluhan umum yang dapat dilihat pada tabel 1 .

Berdasarkan pada pola penularan HIV berdasarkan faktor risiko (lihat tabel 2), infeksi HIV dengan heteroseksual saja sebanyak 4 pasien (30,8\%), homoseksual atau lelaki berhubungan seks dengan lelaki (LSL) saja sebanyak 3 pasien $(23,1 \%), 2$ orang pasien $(15,4 \%)$ tertular virus HIV ini dari suaminya sedangkan heteroseksual dan tatoo, homoseksual dan tatoo, hetero seksual, tatoo, dan narkoba suntik serta pengguna narkoba suntik saja masing-masing sebanyak 1 pasien (7,7\%). Hal ini tampak pada tabel 2 .

Pada penelitian ini subjek penelitian mendapatkan terapi cotrimoxazole sesuai berat badan, kecuali pada 1 subjek yang timbul reaksi alergi pada saat mendapatkan

Tabel 2. Karakteristik sampel berdasarkan pola penularan

\begin{tabular}{lcc}
\hline \multicolumn{1}{c}{ Pola Penularan } & Frekuensi & Persentase \\
\hline Free sex (hetero seksual) & 4 & 30.8 \\
Free sex (hetero seksual), tatoo & 1 & 7.7 \\
Free sex (hetero seksual), tatoo, & 1 & 7.7 \\
narkoba suntik & 3 & 23.1 \\
Free sex (homo seksual) & 1 & 7.7 \\
Free sex (homo seksual), tatoo & 1 & 7.7 \\
Narkoba suntik & 2 & 15.4 \\
Tertular dari suaminya. Suaminya & & \\
free sex &
\end{tabular}

Tabel 3. Data terapi Cotrimoxazole

\begin{tabular}{lccc}
\hline & n & $\begin{array}{c}\text { Mean } \pm \\
\text { Simpangan Baku }\end{array}$ & $\begin{array}{c}\text { Median } \\
(\text { Min - Maks) }\end{array}$ \\
\hline $\begin{array}{l}\text { Terapi } \\
\text { Cotrimoxazole }\end{array}$ & 12 & $3,92 \pm 2,109$ & $3,50(1-7)$ \\
\hline
\end{tabular}

terapi cotrimoxazole. Mean dan median durasi terapi subjek mendapatkan terapi cotrimoxazole sebelum dilakukan FOB adalah 3,92 $\pm 2,109$ hari dan 3,50 hari (1-7), seperti tampak pada tabel 3 .

Hasil pemeriksaan kadar serum LDH subjek penelitian menunjukkan mean kadar serum LDH adalah 554,62 \pm 376,707 U/l dan median adalah $438 \mathrm{U} / \mathrm{l}$ (325-1724), seperti tampak pada tabel 4.

Tabel 4. Data deskriptif kadar serum LDH

\begin{tabular}{lccc}
\hline & n & $\begin{array}{c}\text { Mean } \pm \\
\text { Simpangan Baku }\end{array}$ & $\begin{array}{c}\text { Median } \\
(\text { Min - Maks) }\end{array}$ \\
\hline Serum LDH & 13 & $554,62 \pm 376,707$ & $438(325-1724)$ \\
\hline
\end{tabular}

Hasil pemeriksaan radiologis, dari 13 subjek penelitian, didapatkan kelainan retikulogranuler pattern di kedua lapangan paru sebanyak 10 orang $(76,9 \%)$ dan infiltrat di kedua lapangan paru, infiltrat di paru kanan dan pneumotorak kiri dan pneumotorak kiri masing-masing sebanyak 1 orang $(7,7 \%)$, seperti tampak pada tabel 5 .

Tabel 5. Hasil pemeriksaan foto toraks

\begin{tabular}{lcc}
\hline \multicolumn{1}{c}{ Hasil Pemeriksaan } & Frekuensi & Persentase \\
\hline $\begin{array}{l}\text { Infiltrat di kedua lapangan paru } \\
\text { Infiltrat di paru kanan dan }\end{array}$ & 1 & 7.7 \\
pneumotorak kiri & 1 & 7.7 \\
$\begin{array}{l}\text { Pneumotorak kiri } \\
\text { Retikulogranuler pattern di kedua } \\
\text { lapangan paru }\end{array}$ & 1 & 7.7 \\
\hline Total & 13 & 76.9 \\
\hline
\end{tabular}

Hasil pemeriksaan bronkoskopi pada 13 subjek penelitian, diketahui bahwa subjek yang mengalami penyempitan sebanyak 2 orang $(15,4 \%)$, sedangkan pemeriksaan yang menunjukkan hasil normal sebanyak 11 orang $(84,6 \%)$ seperti tampak pada tabel 6 .

Tabel 6. Hasil pemeriksaan bronkoskopi

\begin{tabular}{lcc}
\hline Hasil Pemeriksaan & Frekuensi & Persentase \\
\hline Normal & 11 & $84,6 \%$ \\
Penyempitan & 2 & $15,4 \%$ \\
\hline
\end{tabular}


Tabel 7. Hasil pemeriksaan Giemsa pada induksi sputum

\begin{tabular}{lcc}
\hline \multicolumn{1}{c}{$\begin{array}{c}\text { Pemeriksaan } \\
\text { Induksi Sputum }\end{array}$} & Frekuensi & Persentase \\
\hline Negatif & 13 & $100 \%$ \\
Positif & 0 & $0 \%$ \\
\hline
\end{tabular}

Berdasarkan hasil pada tabel 7 dapat diketahui bahwa pemeriksaan Giemsa dengan induksi sputum tidak didapatkan hasil yang positif $(0 \%)$.

Berdasarkan hasil pada tabel 8 dapat diketahui bahwa pemeriksaan Giemsa pada cairan bronchoalveolar lavage tidak didapatkan hasil yang positif $(0 \%)$.

Tabel 8. Hasil pemeriksaan Giemsa pada bronchoalveolar lavage

\begin{tabular}{lcc}
\hline \multicolumn{1}{c}{$\begin{array}{c}\text { Pemeriksaan } \\
\text { bronchoalveolar lavage }\end{array}$} & Frekuensi & Persentase \\
\hline Negatif & 13 & $100 \%$ \\
Positif & 0 & $0 \%$ \\
\hline
\end{tabular}

Hasil kultur aerob cairan BAL pada subjek penelitian, didapatkan pertumbuhan kuman pada 8 subjek $(61,5 \%)$ dengan jenis kuman Acinetobacter spp sebanyak 1 subjek (7,7\%), Eschericia coli sebanyak 1 subjek (7,7\%), Klebsiella pneumonia sebanyak 4 subjek $(30,8 \%)$, dan Streptococcus viridans sebanyak 2 subjek $(15,4 \%)$ seperti tampak pada tabel 9.

Hasil kultur jamur cairan BAL pada subjek penelitian didapatkan pertumbuhan jamur pada 10 subjek (76,9\%) dengan hasil jamur Candida spp pada 10 subjek (76,9\%) seperti tampak pada tabel 11 .

Tabel 9. Data kultur aerob

\begin{tabular}{llrc}
\hline Kultur Nerob & & $\mathbf{n}$ & $\mathbf{\%}$ \\
\hline \multirow{3}{*}{ Hasil kultur } & Tumbuh & 8 & 61,5 \\
aerob & Tidak tumbuh & 5 & 38,5 \\
& Total & $\mathbf{1 3}$ & $\mathbf{1 0 0}$ \\
\hline \multirow{5}{*}{ Jenis kuman } & Acinetobacter spp & 1 & 7,7 \\
& Eschericia coli & 1 & 7,7 \\
& Klebsiella pneumonia & 4 & 30,8 \\
& Streptococcus viridans & 2 & 15,4 \\
& Tidak tumbuh & 5 & 38,5 \\
& Total & $\mathbf{1 1 3}$ & $\mathbf{1 0 0}$ \\
\hline
\end{tabular}

Tabel 10. Hasil kultur sensitivitas aerob

\begin{tabular}{|c|c|c|}
\hline No & Jenis Kuman & Antibiotik yang Sensitif \\
\hline 1 & $\begin{array}{l}\text { Klebsiella } \\
\text { pneumonia }\end{array}$ & Meropenem, Amikasin \\
\hline 2 & $\begin{array}{l}\text { Klebsiella } \\
\text { pneumonia }\end{array}$ & Meropenem, Cefoxitine \\
\hline 3 & $\begin{array}{l}\text { Klebsiella } \\
\text { pneumonia }\end{array}$ & $\begin{array}{l}\text { Ceftazidime, Aztreonam, } \\
\text { Amikacin, Piperazilin- } \\
\text { tazobactam, Cefepime, Cefoxitine }\end{array}$ \\
\hline 4 & $\begin{array}{l}\text { Streptococcus } \\
\text { viridans }\end{array}$ & $\begin{array}{l}\text { Piperazilin-tazobactam, } \\
\text { Gentamicin, Tetracyclin }\end{array}$ \\
\hline 5 & Eschericia coli & $\begin{array}{l}\text { Cefoxitine, Gentamicin, } \\
\text { Meropenem, Piperazilin- } \\
\text { tazobactam, Amikacin }\end{array}$ \\
\hline 6 & Acinetobacter spp & Gentamicin \\
\hline 7 & $\begin{array}{l}\text { Streptococcus } \\
\text { viridans }\end{array}$ & $\begin{array}{l}\text { Meropenem, Piperazilin- } \\
\text { tazobactam }\end{array}$ \\
\hline 8 & $\begin{array}{l}\text { Klebsiella } \\
\text { pneumonia }\end{array}$ & $\begin{array}{l}\text { Meropenem, Cefoxitine, } \\
\text { Amikacin, Piperazilin- } \\
\text { tazobactam, Cefepime }\end{array}$ \\
\hline
\end{tabular}

Tabel 11. Data kultur jamur

\begin{tabular}{llcc}
\hline \multicolumn{1}{c}{ Kultur Jamur } & & $\mathbf{n}$ & $\mathbf{\%}$ \\
\hline \multirow{3}{*}{ Hasil kultur jamur } & Tumbuh & 10 & 76,9 \\
& Tidak tumbuh & 3 & 23,1 \\
& Total & $\mathbf{1 3}$ & $\mathbf{1 0 0}$ \\
\hline \multirow{3}{*}{ Jenis jamur } & Candida spp & 10 & 76,9 \\
& Tidak tumbuh & 3 & 23,1 \\
& Total & $\mathbf{1 1 3}$ & $\mathbf{1 0 0}$ \\
\hline
\end{tabular}

\section{Komplikasi}

Tidak didapatkan komplikasi selama tindakan induksi sputum dengan $\mathrm{NaCl} 3 \%$. Komplikasi yang terjadi selama tindakan BAL yaitu 1 subjek mengalami hipoksemia durante tindakan BAL dan 2 pasien memburuk dan meninggal setelah 2 hari tindakan BAL.

\section{PEMBAHASAN}

Sampel penelitian ini berjumlah 13 orang, yang merupakan pasien PCP yang ditegakkan berdasarkan diagnosis klinis dan radiologis yang terdiri dari $11(84,6 \%)$ pasien laki-laki dan $2(15,4 \%)$ perempuan. Ditjen P2PL melaporkan rasio prevalensi HIV antara laki-laki dan perempuan adalah 2:1, karena laki-laki dewasa lebih sering melakukan aktivitas sosial. Angka kejadian PCP pada HIV lebih tinggi pada laki-laki dibanding perempuan. Perbedaan tersebut kemungkinan disebabkan karena perbedaan perilaku dalam mencari perawatan kesehatan antara laki- 
laki dan perempuan sehingga lebih banyak kasus HIV pada laki-laki yang dilaporkan. Selain itu juga adanya perilaku seksual bebas yang lebih sering dilakukan oleh laki-laki.

Rentang umur sampel penelitian antara 21 tahun sampai 65 tahun, jumlah kelompok umur yang paling banyak adalah antara umur 31-40 tahun sebanyak 7 orang $(53,8 \%)$, diikuti kelompok umur 41-50 tahun sebanyak 3 orang $(23,1 \%)$ dan kelompok umur 50 tahun ke atas sebanyak 2 orang $(15,4 \%)$. Kelompok umur paling sedikit adalah kelompok umur antara 21-30 tahun sebanyak 1 orang (7,7\%), dengan rata-rata usia 40 tahun. Penelitian ini sesuai dengan laporan Ditjen P2PL Kemenkes RI di mana infeksi HIV paling banyak terjadi pada kelompok usia produktif 25-49 tahun. ${ }^{13}$

Berdasarkan pola penularan HIV berdasarkan faktor risiko, infeksi HIV dengan heteroseksual saja sebanyak 4 pasien (30,8\%), homoseksual atau lelaki berhubungan seks dengan lelaki (LSL) saja sebanyak 3 pasien $(23,1 \%)$, 2 orang pasien $(15,4 \%)$ tertular virus HIV ini dari suaminya sedangkan heteroseksual dan tatoo, homoseksual dan tatoo, hetero seksual, tatoo, dan narkoba suntik serta pengguna narkoba suntik saja masing-masing sebanyak 1 pasien $(7,7 \%)$. Hal ini sesuai dengan data Ditjen P2PL Kemenkes RI, faktor risiko infeksi HIV dominan terjadi pada heteroseksual diikuti kelompok pengguna napza suntik (penasun) dan kelompok homoseksual "lelaki berhubungan seksual dengan lelaki” (LSL) dan kasus lain-lain. Pada kasus HIV yang mengenai 2 pasien wanita, hal ini disebabkan mereka tertular dari suaminya, di mana suaminya memiliki faktor risiko hubungan seksual bergonta-ganti pasangan. ${ }^{13}$

Keluhan utama pasien saat datang pertama kali ke rumah sakit adalah sesak napas (100\%) dengan lama rata-rata keluhan sesak napas 12,85 hari. Keluhan umum yang dirasakan pasien yaitu batuk pada semua pasien dengan dominan batuk kering dengan dahak sulit keluar pada 11 pasien $(84,6 \%)$. Hal ini sesuai dengan penelitian Silva dkk yang menyebutkan keluhan utama dari 45 subjek penelitiannya, didapatkan keluhan utama sesak napas dan batuk kering pada 28 orang $(62,6 \%){ }^{12}$

Pada penelitian ini subjek penelitian mendapatkan terapi cotrimoxazole sesuai berat badan, kecuali pada 1 subjek yang timbul reaksi alergi pada saat mendapatkan terapi cotrimoxazole. Mean dan median durasi terapi subjek mendapatkan terapi cotrimoxazole sebelum dilakukan FOB adalah 3,92 $\pm 2,109$ hari dan 3,50 hari (1-7). Pada penelitian ini didapatkan $6(46,2 \%)$ subjek penelitian yang pernah mendapatkan terapi ARV dan 7 (53,8\%) subjek penelitian yang belum pernah mendapatkan terapi ARV.

Pemberian ARV segera pada pasien PCP-HIV memberikan manfaat yang signifikan yaitu menurunkan angka mortalitas dan progresi menjadi AIDS. Hal ini disampaikan oleh Manzardo dkk, ${ }^{14}$ di mana mereka meneliti kapan waktu terbaik untuk memulai terapi ARV pada berbagai kondisi infeksi oportunistik termasuk PCP. Subjek dibagi menjadi dua kelompok berdasarkan waktu inisiasi ARV. Dikatakan awal bila subjek mendapatkan terapi ARV kurang dari 30 hari setelah terdiagnosis infeksi HIV dan lanjut bila subjek mendapatkan terapi ARV lebih dari 30 hari. Didapatkan mortalitas pada kelompok awal 2,1\% dibandingkan mortalitas pada kelompok lanjut 15,8\% dengan $\mathrm{p}<0,001$. Pada progresi menjadi AIDS kelompok awal $16 \%$ dan kelompok lanjut 30,7\% dengan p 0,014.

Hasil pemeriksaan kadar serum LDH subjek penelitian menunjukkan mean kadar serum LDH adalah $554,62 \pm 376,707 \mathrm{U} / 1$ dan median adalah $438 \mathrm{U} / 1$ (3251724). Gambaran radiologis pada 13 pasien, didapatkan gambaran dominan berupa kelainan retikulogranuler pattern di kedua lapangan paru sebanyak 10 orang $(76,9 \%)$ dan infiltrat di kedua lapangan paru, infiltrat di paru kanan dan pneumotorak kiri dan pneumotorak kiri masing-masing sebanyak 1 orang $(7,7 \%)$. Hasil pemeriksaan bronkoskopi pada penelitian ini didapatkan kelainan pada 2 pasien $(15,4 \%)$ yaitu adanya penyempitan pada lobus superior, lingula dan inferior paru kiri. Hal ini disebabkan karena adanya pneumotoraks kiri pada kedua pasien tersebut. Pada 11 pasien $(84,6 \%)$ lainnya menunjukkan hasil bronkus normal.

Tidak didapatkan komplikasi selama tindakan induksi sputum dengan $\mathrm{NaCl}$ 3\%. Komplikasi yang terjadi selama tindakan BAL yaitu 1 subjek mengalami hipoksemia durante tindakan BAL dan 2 pasien memburuk dan meninggal 2 hari setelah tindakan BAL. Pada kejadian 2 pasien yang meninggal, hal ini kemungkinan disebabkan oleh progresivitas penyakitnya. Penelitian Silva dkk, ${ }^{12}$ tidak didapatkan komplikasi pada tindakan induksi sputum dan BAL.

Hasil pemeriksaan Giemsa pada induksi sputum menunjukkan bahwa dari 13 sampel, tidak didapatkan hasil yang positif (0\%). Hasil ini lebih rendah dibanding dengan Penelitian Silva dkk, induksi sputum untuk menegakkan diagnosis PCP memiliki sensitivitas 58,5\%, spesifisitas $81,8 \%$, positif predictive value (PPV) 90,9\%, negatif predictive value (NPV) 39,1\% dan keakuratan $64,4 \% .{ }^{12}$ Penelitian Carmona dan Limper ${ }^{1}$, induksi sputum memiliki sensitivitas 50-90\% untuk menegakkan diagnosis PCP.

Prasetyo $\mathrm{H} \mathrm{dkk}{ }^{15}$ melakukan penelitian pada bulan Agustus sampai bulan Oktober 2012 berhasil dikumpulkan 18 sampel dahak sisa periksaan penderita HIV dan AIDS yang sedang menjalani rawat inap di RSUD Dr. Soetomo Surabaya. Dengan cara mengecat Giemsa, enam sampel dahak diketahui positif Pneumocystis (33,33\%).

Pada penelitian ini didapatkan hasil yang lebih rendah. Hal ini mungkin disebabkan karena adanya perbedaan prosedur, keterampilan petugas laboratorium, jumlah sampel, berat dan luasnya penyakit pasien. Hasil yang diperoleh mungkin lebih tinggi jika teknik induksi dilakukan lebih dari 1 kali. Kualitas spesimen dan banyaknya patogen yang ditemukan pada sputum (parasite load) mempunyai korelasi dengan pemeriksaan yang dilakukan. Kemungkinan lainnya yang menyebabkan hasil negatif pada penelitian ini adalah pemberian terapi cotrimoxazole (mean 4 hari) dan pemberian terapi ARV. Munksgaard ${ }^{16}$ mengatakan sisa organisme Pneumocystis pada spesimen BAL setelah 
selesai terapi lengkap PCP (14-21 hari) sebagian besar sudah tidak terlihat lagi. Adanya perbaikan respons klinis setelah pemberian cotrimoxazole setelah terapi hari ke-3 atau hari ke-4.

Pemberian terapi ARV kemungkinan juga menyebabkan hasil penelitian yang negatif. Penelitian Castro dkk, ${ }^{17}$ pemberian terapi ARV diberikan dalam 14 hari setelah didiagnosis infeksi oportunistik dibandingkan pemberian terapi ARV setelah terapi infeksi oportunistik selesai. Perbaikan outcome secara klinis tampak pada pasien yang diberikan ARV secara dini dan angka kematian akan menurun dari $63 \%$ pada pasien yang tidak mendapat terapi ARV menjadi $25 \%$ pada pasien yang menerima terapi ARV selama perawatan.

Hasil pemeriksaan Giemsa pada cairan BAL menunjukkan bahwa dari 13 sampel, tidak didapatkan hasil yang positif $(0 \%)$. Hasil penelitian ini bisa bervariasi, hal ini disebabkan karena adanya perbedaan prosedur yang digunakan, pengalaman dokter yang mengerjakan, jumlah saline yang dimasukkan, jumlah sampel penelitian, pengiriman spesimen atau tingkat spesialisasi laboratorium. Kemungkinan lainnya adalah bahwa subjek penelitian telah mendapat terapi cotrimoxazole selama rata-rata 4 hari.

Penelitian Chawla dkk ${ }^{18}$, ditemukan 1 pasien dengan hasil Polymerase Chain Reaction (PCR) negatif tetapi secara klinis didiagnosis sebagai PCP. PCR dapat memberikan hasil negatif palsu pada kasus dimana tidak ditemukan kista PCP. Hal ini juga dapat ditemukan pada subjek yang telah menerima profilaksis cotrimoxazole. Penelitian Chawla juga menyebutkan bahwa sebagian besar hasil PCP negatif (12 dari 32 pasien), mempunyai diagnosis tuberkulosis paru dan pneumonia bakterial atau penyakit paru interstitial. Pada penelitian ini, semua subjek (13 sampel) didapatkan hasil negatif PCP dan didapatkan 8 subjek $(61,5 \%)$ dengan hasil pneumonia bakterial dan kuman terbanyak ditemukan Klebsiella pneumonia pada 4 subjek (30,8\%).

Pada penelitian ini tidak didapatkan hasil pengecatan Giemsa yang positif pada seluruh subjek penelitian. Hasil pengecatan Giemsa negatif dapat disebabkan oleh sedikitnya jumlah kista atau tropozoit pada specimen (parasite load). Hal ini diungkapkan oleh Nowaseb dkk yang meneliti $P$. jiroveci pada sputum pasien HIV dan TB di Namibia menggunakan Polymerase Chain Reaction (PCR) dan pengecatan Gomori methenamine silver. $P$. jiroveci terdeteksi pada 25 pasien dari 475 pasien menggunakan PCR dan 17 pasien menggunakan pengecatan Gomori methenamine silver. Selain itu kualitas spesimen yang buruk juga dapat menyebabkan sulitnya mendeteksi $P$. jiroveci. ${ }^{19}$

Pemeriksaan PCR dilaporkan dapat meningkatkan sensitivitas deteksi Pneumocystis hingga 86-100\% dari sediaan induksi sputum. Beberapa penelitian menggunakan PCR telah berhasil mendeteksi $P$. jiroveci pada individu yang sediaan pewarnaannya negatif. Flori $\mathrm{dkk}^{20}$ membandingkan pemeriksaan real-time PCR dengan PCR konvensional serta teknik pewarnaan dalam diagnosis PCP. Nilai sensitivitas dan spesifisitas pemeriksaan real-time PCR adalah $100 \%$ dan $84,9 \%$, sementara itu PCR konvensional adalah $100 \%$ dan $87 \%$, sedangkan teknik pewarnaan adalah $60 \%$ dan $100 \%$. Hasil positif semu menggunakan teknik biologi molekuler cukup sering terjadi dibandingkan diagnosis PCP secara klinis. Beberapa penelitian melaporkan bahwa hasil positif semu menggunakan teknik pemeriksaan PCR konvensional berkisar antara 2-21\% pada pasien-pasien tanpa gejala yang diduga berada dalam kondisi carrier. Hasil negatif semu lebih sering ditemukan pada pemeriksaan menggunakan teknik pewarnaan konvensional. Hasil ini perlu mendapat perhatian, terutama pada pasien yang diduga secara klinis mengalami PCP, ternyata pasien kemudian dilaporkan memperlihatkan perburukan klinis dalam waktu singkat, dan angka kematian mencapai $35,4 \% .^{20,21}$

Lautenschlager $\mathrm{dkk}^{22}$ mengungkapkan hal yang sama, di mana mereka membandingkan deteksi Pneumocystic carinii menggunakan imunofluoresens dan pengecatan Gomori methenamine silver pada 553 cairan BAL. $P$. carinii ditemukan pada 84 spesimen (15\%) menggunakan kedua metode. Pada penelitian ini sebanyak 68 spesimen positif pada pengecatan Gomori methenamine silver dan 72 spesimen positif pada pemeriksaan imunofluoresens. Lautenschlager dkk mengatakan angka kepositifan sedikit lebih tinggi pada pemeriksaan imunofluoresens, tetapi hal ini tidak signifikan. Pada beberapa spesimen yang hanya mengandung beberapa kista, lebih mudah untuk mendeteksi $P$. carinii menggunakan pemeriksaan imunofluoresens. Hal ini dapat disebabkan oleh terangnya pengecatan fluoresens pada latar belakang gelap, sehingga bila hanya terdapat satu kista pada slide tersebut tetap terlihat jelas. Pada pengecatan Gomori methenamine silver deteksi P. carinii berdasarkan morfologi kista. Sehingga hasil negatif palsu dapat disebabkan oleh sedikitnya jumlah kista pada spesimen. Pemeriksaan antibodi fluoresens walaupun spesifik tetapi membutuhkan waktu lebih lama, membutuhkan mikroskop fluoresens dan tidak dapat melihat detil morfologi jamur. ${ }^{23}$

Berbagai variasi antibodi monoklonal untuk mendeteksi keberadaan $P$. jiroveci pada spesimen biopsi dan sitologi. Antibodi ini spesifik dan sensitif untuk mendeteksi bentuk kista dan trofozoit $P$. jiroveci. Metode imunohistokimia sangat berguna pada spesimen sputum induksi dan cairan BAL yang dapat mengandung banyak mukus argyrophilic dan debris yang dapat menghalangi pandangan terhadap jamur. Metode imunohistokimia juga bermanfaat untuk mendeteksi $P$. jiroveci pada pasien yang telah mendapatkan terapi dan pada infeksi pneumocystis ekstra paru. ${ }^{23}$

Penelitian Linssen $\mathrm{dkk}^{24}$, dari 83 sampel dengan pemeriksaan mikroskopis konvensional hasilnya negatif PCP, 69 sampel memang negatif dengan pemeriksaan PCR dan 14 pasien dinyatakan positif dengan pemeriksaan PCR. Pada pasien kelompok risiko tinggi PCP dengan hasil pemeriksaan mikroskopis konvensional hasilnya negatif, pemeriksaan mikroskopik harus dievaluasi ulang dan pasien seharusnya dievaluasi secara klinis dan tetap 
menerima terapi PCP dengan gejala klinis dicurigai PCP. Penelitian Tia dkk ${ }^{25}$, dari 66 pasien HIV dan 36 pasien nonHIV, didapatkan $46(45,1 \%)$ sampel positif PCP dengan pemeriksaan mikroskopis konvensional dan 91 (89,2\%) pasien hasilnya positif PCP dengan pemeriksaan PCR.

Pada penelitian ini, tidak bisa dibandingkan hasil pemeriksaan giemsa induksi sputum terhadap giemsa cairan BAL karena semua hasil pemeriksaannya tidak ada yang positif. Pada penelitian ini, didapatkan beberapa keterbatasan penelitian yaitu: sedikitnya sampel penelitian ( $\mathrm{n}=13)$, sedikitnya jumlah tropozoit Pneumocystis jiroveci pada sediaan, subjek penelitian telah mendapatkan terapi Cotrimoxazole (mean 4 hari), induksi sputum hanya dilakukan $1 \mathrm{x}$.

\section{KESIMPULAN}

Hasil penelitian ini menunjukkan, dari 13 subjek penelitian pemeriksaan Giemsa pada induksi sputum tidak didapatkan hasil yang positif $(0 \%)$, hasil pemeriksaan Giemsa pada cairan BAL dari 13 subjek penelitian, tidak didapatkan hasil yang positif $(0 \%)$ serta pemeriksaan Giemsa teknik induksi sputum dan Giemsa pada BAL tidak bisa dibandingkan karena tidak didapatkan hasil yang positif.

\section{DAFTAR PUSTAKA}

1. Carmona EM, Limper AH. Update on the diagnosis and treatment of Pneumocystis Pneumonia. Ther Adv Respir Dis 2011; 5: 41-59.

2. Crothers, K, Huang, L, Goulet, JL, et al. HIV infection and risk for incident pulmonary diseases in the combination antiretroviral therapy era. Am J Respir Crit Care Med. 2011; 183(3), 388-395.

3. Palewar MS, Dhanvijay AG, More SR. Prevalence of Human Immunodeficiency Virus associated bacterial and fungal respiratory tract infections. Indian journal of basic and applied medical research. 2013; September: Issue-8, Vol. 2, p. 880-5.

4. Lee KY, Ho CC, Ji DD, et al. Etiology of pulmonary complications of human immunodeficiency virus-1-infected patients in Taiwan in the era of combination antiretroviral therapy: A prospective observational study. Journal of Microbiology, Immunology and Infection. 2013; 46, 433-40.

5. Boonsarngsuk V, Sirilak S, Kiatboonsri S. Acute respiratory failure due to Pneumocystis pneumonia: outcome and prognostic factors. International Journal of Infectious Diseases. 2009; 13, 59-66.

6. Chakaya M. Pulmonary Manifestations of HIV Disease. HIV Infection in the Era of Highly Active Antiretroviral Treatment and Some of Its Associated Complications. www.intechopen.com. 2011.

7. Huang L, Cattamanchi A, Davis J, et al. HIV-Associated Pneumocystis Pneumonia. Proc Am Thorac Soc. 2011; 8: 294-300.

8. Dockrell DH, Breen R, Lipman M, Miller RF. Pulmonary opportunistic infections. In British HIV Association and British Infection Association Guidelines for the Treatment of Opportunistic
Infection in HIV-seropositive Individuals 2011. HIV Medicine. 2011; 12(Suppl. 2), 25-42.

9. Jain P, Sandur S, Meli Y, Arroliga A.C, Stoller J.K, Mehta A.C. Role of flexible bronchoscopy in immunocompromised patients with lung infiltrates. CHEST. 2004; 125: 712-22.

10. Peckham D, Elliott MW. Pulmonary infiltrates in the immunocompromised: diagnosis and management. Thorax. 2002; 57(suppl II): ii, 3-7.

11. Velez L, Correa LT, Maya MA, et al. Diagnostic accuracy of bronchoalveolar lavage samples in immunosuppressed patients with suspected pneumonia: analysis of a protocol. Respiratory medicine. 2007; 101: 2160-7.

12. Silva RM, Bazzo ML, Borges AA. Induced sputum versus bronchoalveolar lavage in the diagnosis of Pneumocystis jiroveci pneumonia in human immunodeficiency virus-positive patients. The brazilian journal of infectious disease. 2007; 11(6): 549-53.

13. Ditjen P2PL Kemenkes RI. Infodatin: pusat data dan informasi kementerian kesehatan RI. 2014.

14. Manzardo C, Esteve A, Ortega N, et al. Optimal timing for initiation of highly active antiretroviral therapy in treatment-naive human immunodeficiency virus-I-infected individuals presenting with AIDS-defining disease: the experience of the PISCIS cohort. Clinical microbiology infection. 2013; 19: 646-53.

15. Prasetyo RH. Pnemocystis pneumonia (PCP) di penderita HIV dan AIDS dengan kelainan paru. Indonesian journal of clinical pathology and medical laboratory. Vol. 20, No. 1, November 2013 Hal: 34-7.

16. Munksgaard B. Pneumocystis jiroveci (formerly Pneumocystis carinii). American Journal of Transplantation. 2004; 4: 135-41.

17. Castro J.G, Bryant M.M. Management of Pneumocystis jirovecii pneumonia in HIV infected patients: current options, challenges and future directions. HIV/AIDS - Research and Palliative Care. 2010; 2: $123-34$.

18. Chawla K, Martena S, Gurung B, Mukhopadhyay C, Varghese GK, Bairy I. Role of PCR for diagnosing Pneumocystis jirovecii pneumonia in HIV-infected individuals in a tertiary care hospital in India. Indian J Pathol Microbiol. 2011; 54: 326-9.

19. Nowaseb V, Gaeb E, Fraczek MG, Richardson MD, Denning DW Frequency of Pneumocystis jiroveci in sputum from HIV and TB patients in Namibia. Journal infection development countries. 2004: 8(3); 349-57.

20. Flori MW, Sant CA, Kim EJ, et al. Severity and outcomes of Pneumocystis pneumonia in patients newly diagnosed with HIV infection: an observational cohort study. Scand journal infectious disease. 2009; 41(9): 672-8.

21. Rozaliyani A, Antariksa B, Dianiati KS, Wahyuningsih R. Pemeriksaan Real-time PCR dalam diagnosis Pneumonia Pneumocystis. J Respir Indo Vol. 32, No. 3, Juli 2011

22. Lautenschlanger I, Lyytikainen O, Jokipii L, et al. Immunodetection of Pneumocystis carinii in bronchoalveolar lavage specimens compared with methenamine silver stain. Journal of clinical microbiology. 1996: 34(3); 728-30.

23. Haque AK, Adegboyega PA. Pneumocystis jiroveci pneumonia. Dail and hamar's pulmonary pathology volume I non neoplastic lung disease $3^{\text {rd }}$ ed. 2008: 13; 505-6.

24. Linssen CFM, Jacobs JA, Beckers P, et al. Inter-laboratory comparison of three different real-time PCR assays for the detection of Pneumocystis jiroveci in bronchoalveolar lavage fluid samples. Journal of Medical Microbiology. 2006; 55: 1229-35.

25. Tia T, Putaporntip C, Kosuwin R, et al. A highly sensitive novel PCR assay for detection of Pneumocystis jiroveci DNA in bronchoalveolar lavage specimens from immunocompromised patients. Clinical microbiology infection. 2012; 18: 598-603. 